Original Research Article

\title{
Immunosuppressant effect of Boswellia serrata extract on CFA induced arthritis in rats
}

\author{
Sarvesh Singh ${ }^{1}$, Rajendra Kumar ${ }^{1}$, Anil Kumar Saksena1, Rishi Pal ${ }^{1}$, \\ Riddhi Jaiswal' ${ }^{2}$, Rahul Kumar ${ }^{1 *}$
}

${ }^{1}$ Department of Pharmacology,

${ }^{2}$ Department of Pathology, King George's Medical University, Lucknow, Uttar Pradesh, India

Received: 10 August 2018

Accepted: 31 August 2018

*Correspondence to:

Dr. Rahul Kumar,

Email: rahulkgmu@gmail.com

Copyright: (C) the author(s), publisher and licensee Medip Academy. This is an openaccess article distributed under the terms of the Creative Commons Attribution NonCommercial License, which permits unrestricted noncommercial use, distribution, and reproduction in any medium, provided the original work is properly cited.

\begin{abstract}
Background: Rheumatoid arthritis (RA) is an immune-mediated arthropathy, so for the treatment disease modifying antirheumatoid drugs are required. In this study we are evaluating the immunomodulatory property of Boswellia serrata extract (BSE) as an alternative medicine.

Methods: Complete Freund's adjuvant (CFA), $0.1 \mathrm{ml}$ was injected intradermally in the footpad of left hind paw in 36 Wistar rats to induce RA. Animals were divided into 6 groups. BSE in the doses of $45 \mathrm{mg} / \mathrm{kg}, 90 \mathrm{mg} / \mathrm{kg}$ and $180 \mathrm{mg} / \mathrm{kg}$ was administered and cyclophosphamide as standard drug. Various parameters as body weight, paw thickness, ankle diameter, paw volume, arthritis index, TNF$\alpha$ and histopathological changes were analyzed.

Results: Marked reduction in paw thickness, ankle diameter, paw volume, arthritis index and an improved body weight was found in high dose BSE $(180 \mathrm{mg} / \mathrm{kg})$ group but the effect was lesser than standard drug Cyclophosphamide.
\end{abstract}

Conclusions: BSE has significant potential as an alternative medicine for treatment of autoimmune diseases like rheumatoid arthritis.

Keywords: Boswellia serrata extract, Complete Freund's adjuvant, Cyclophosphamide, Rheumatoid arthritis

\section{INTRODUCTION}

RA is the most common inflammatory and immunemediated arthropathy with prevalence of approximately $0.75 \%$ in India. Immune mediated inflammation induces a cascade of events inducing synovitis and ultimately chronic destructive arthritis. ${ }^{1}$

The clinical picture of pain, stiffness, swelling, and joint destruction seen in RA is a result of chronic inflammation of the synovium, characterized by interactions of fibroblast-like synoviocytes with cells of the innate immune system, including macrophages, dendritic cells, mast cells and NK cells, as well as cells of the adaptive immune system, B and T lymphocytes. ${ }^{2}$ In RA there is abundant evidence that the innate immune system is persistently activated, as evidenced by the continual expression of macrophage derived cytokines such as TNF $\alpha$, IL-1 and IL-6. Many immunosuppressant drugs improve the clinical outcomes and pathogenesis of the disease. $^{3}$

Extract of Boswellia has been found to possess antiinflammatory as well as immunomodulatory property. ${ }^{4}$ Result of previous study shows that Boswellia serrata suppresses IL-1 $\beta$, TNF- $\alpha$, IFN- $\gamma$ and enhance production IL-10 in Collagen induced arthritis (CIA) rats. Proinflammatory cytokines IL- $1 \beta$, TNF- $\alpha$, IFN- $\gamma$ and as well as IL-10 have central role in the perpetuation of 
chronic inflammation and tissue damage during progression of RA. ${ }^{5}$ The ability to inhibit proinflammatory cytokines and modulation of antioxidant status suggest that the protective effect of BSE on arthritis in rats might be mediated via the modulation of immune system.

\section{METHODS}

The study was commenced in the Department of Pharmacology, King George's Medical University (K.G.M.U), Lucknow, after getting approval (Research project No.72/IAEC/2016) by the Institutional Animal Ethics Committee.

\section{Experimental animals}

This study was conducted on 36 healthy adult male Wistar rats having an almost similar physical constitution (in terms of age, body weight), weighing between 150-200gm, 6 in each group. They were kept under standard laboratory conditions of temperature $\left(25 \pm 2^{\circ} \mathrm{C}\right)$, humidity $(55 \pm 5 \%)$ and 12 hours light-dark cycle controlled environment. They were provided pellet food and water ad libitum.

\section{Induction of rheumatoid arthritis}

On day 0 Complete Freund's adjuvant (CFA), 0.1ml, was injected intradermally in the footpad of left hind paw in rats barring control group. All rats studied for a secondary lesion of arthritis. The treatment was scheduled from day 12 to day 22 . Usually secondary lesions develop by 10-12 days, which are characterized by inflammation of noninjected sites (right hind limb, fore limbs, ears, nose and tail). The development of secondary lesions in the model is non-infectious, and it is suggested to be result of a generalized immune response to the components of tubercle bacilli, disseminated after local administration. ${ }^{6,7}$ During the entire course of study, the standard protocols were followed. Baseline measurement for parameters body weight, paw thickness, and paw volume was done on day 0 . Subsequently, above mentioned parameters including arthritic index and TNF- $\alpha$ was measured on day 12 and 22 . On day 22 all rats were sacrificed by using a high dose of Pentobarbitone $\left(150 \mathrm{mg} / \mathrm{kg}\right.$ i.p). ${ }^{8}$ The inflammed limbs were excised above the ankle joints and examined for a pathological finding of rheumatic arthritis.

\section{Drug and chemicals}

Complete Freund's Adjuvant was purchased from Sigma Aldrich Chemical Co, USA. Boswellia serrata $125 \mathrm{mg}$ tablets were purchased from Himalaya Healthcare Co, India. Cyclophosphamide 50mg tablet was purchased from Jagsonpal Pharmaceuticals. An ELISA kit for TNF- $\alpha$ was purchased from Diaclone, France.

Cyclophosphamide $7 \mathrm{mg} / \mathrm{kg}$ (group-3) and BSE $45 \mathrm{mg} / \mathrm{kg}$, $90 \mathrm{mg} / \mathrm{kg}, 180 \mathrm{mg} / \mathrm{kg}$ (group-4, 5 and 6) in distilled water for oral administration to each rat. ${ }^{9,10}$

\section{Arthritic parameters}

\section{Arthritic index}

Rats were kept under observation and periodic parametric evaluation for arthritis was recorded on day 0 , day 12 and day 22. The severity of arthritis was evaluated by arthritic score grading system. ${ }^{11}$ Severity of the secondary lesions are graded by adding all scores of individual rat (Table 1).

\section{Measurement of body weight}

The body weight of all rats was recorded on day 0 , day 12 and day 22 in the experiment. The difference of body weight was calculated on day 12 and day 22 to determine the change in body weight amongst all groups of the rat.

\section{Measurement of paw thickness}

Paw thickness was measured on day 0 , day 12 and day 22 to assess inflammation as a secondary lesion on noninjected limb. The percentage inhibition of paw thickness was calculated using the formula:

Percentage inhibition $=(\mathrm{Tc}-\mathrm{Tt}) \mathrm{X} 100 / \mathrm{Tc}$

Where, Tc is mean change in paw thickness of arthritis control group and $\mathrm{Tt}$ is mean change in paw thickness of treated group.

\section{Measurement of paw volume}

Paw volume of the injected limb was measured on day 0 , day 12 and day 22 by immersed vertically to the level of the lateral malleolus in the plethymometer. Mean change in paw volume was calculated and percentage inhibition of paw oedema was calculated using the formula:

Percentage inhibition $=(\mathrm{Vc}-\mathrm{Vt}) \times 100 / \mathrm{Vc}$

Where,

$\mathrm{Vc}$ is mean changes in paw volume of control group.

$\mathrm{Vt}$ is mean changes in paw volume of treated group-s.

\section{Measurement of TNF alpha}

On day 12 and 22 blood sample was withdrawn from the retro-orbital route and serum was separated by centrifugation. Serum level of TNF- $\alpha$ was determined by using commercially available enzyme-linked immunosorbent assay (ELISA) kits.

\section{Histopathological examination}

Right hind limb tissue from diseased, treated and control rats were excised and fixed in $10 \%$ buffer formalin solution. 


\section{Statistical analysis}

The recorded data were analyzed by Paired t-test and ANOVA. The data was analyzed and represented as percentage inhibition, mean difference and $\mathrm{P}$ value.

\section{RESULTS}

Effects of BSE on Body weight as compared to cyclophosphamide

On day 0 , bodyweight was measured of each rat from every group and taken as baseline values. During the course of study, the mean $\%$ increase in weight in control group was $4.56(\mathrm{p}=0.06)$, from day 0 to day 12 and mean $\%$ increase in weight was $4.05(\mathrm{p}=0.76)$ from day 12 to day 22 (Table 2).
Table 1: Arthritic score grading system.

\begin{tabular}{|lll|}
\hline \multirow{2}{*}{ Ears } & absence of nodules and redness & Score \\
\cline { 2 - 3 } & presence of nodules and redness & 1 \\
\hline \multirow{3}{*}{ Nose } & no swelling of connective tissue & 0 \\
\cline { 2 - 3 } & $\begin{array}{l}\text { intensive swelling of connective } \\
\text { tissue }\end{array}$ & 1 \\
\hline \multirow{2}{*}{ Tail } & absence of nodules & 0 \\
\cline { 2 - 3 } & presence of nodules & 1 \\
\hline \multirow{2}{*}{ Forepaws } & absence of inflammation & 0 \\
\cline { 2 - 3 } & inflammation of at least 1 joint & 1 \\
\hline \multirow{3}{*}{$\begin{array}{l}\text { Hind } \\
\text { paws }\end{array}$} & absence of inflammation & 0 \\
\cline { 2 - 3 } & slight inflammation & 1 \\
\cline { 2 - 3 } & moderate inflammation & 2 \\
\cline { 2 - 3 } & marked inflammation & 3 \\
\hline
\end{tabular}

Table 2: Change in body weight (recorded in grams) of different groups of animals on day 0, 12 and 22.

\begin{tabular}{|c|c|c|c|c|c|c|c|c|}
\hline \multirow{3}{*}{ Variables } & \multirow{3}{*}{ Groups } & \multicolumn{2}{|c|}{ Days of study } & & \multicolumn{2}{|l|}{ Day 0-12 } & \multicolumn{2}{|l|}{ Day 12-22 } \\
\hline & & Day 0 & Day 12 & Day 22 & Mean \% & $\mathbf{P}$ & Mean \% & \\
\hline & & Mean \pm SD & Mean \pm SD & Mean \pm SD & change & value & change & value \\
\hline \multirow{6}{*}{$\begin{array}{l}\text { Body } \\
\text { weight }\end{array}$} & I & $188.5 \pm 5.577$ & $197.5 \pm 1.871$ & $205.5 \pm .3 .834$ & -4.56 & 0.060 & -4.05 & 0.760 \\
\hline & II & $186.83 \pm 6.113$ & $171.17 \pm 10.167$ & $163.67 \pm 10.893$ & 9.15 & 0.129 & 4.38 & 0.398 \\
\hline & III & $182.67 \pm 8.664$ & $172.83 \pm 7.705$ & $187.5 \pm 7.259$ & 5.69 & $0.002 *$ & -8.49 & $0.001 *$ \\
\hline & IV & $182.83 \pm 7.96$ & $171.5 \pm 8.666$ & $182.67 \pm 7.659$ & 6.61 & 0.129 & -6.51 & $0.001 *$ \\
\hline & $\mathrm{V}$ & $180.5 \pm 8.385$ & $170.33 \pm 8.017$ & $182.83 \pm 8.542$ & 5.97 & 0.168 & -7.34 & $0.001 *$ \\
\hline & VI & $180.5 \pm 7.007$ & $170.83 \pm 5.981$ & $186.33 \pm 8.335$ & 5.66 & $0.004 *$ & -9.07 & $0.005^{*}$ \\
\hline
\end{tabular}

All values are represented in mean \pm SD; values on day 0 and 12 represent the value before treatment and values on day 22 are after treatment; $n=6 /$ group; all treatment administered orally

*The mean difference is significant at the level of 0.05

Table 3: Change in body weight of treated groups as compared with arthritic control group.

\begin{tabular}{|c|c|c|c|c|c|c|c|c|}
\hline \multirow[b]{2}{*}{ Variables } & \multirow{2}{*}{\multicolumn{2}{|c|}{ Groups }} & \multicolumn{2}{|l|}{ Days 0} & \multicolumn{2}{|l|}{ Day 12} & \multicolumn{2}{|l|}{ Day 22} \\
\hline & & & $\begin{array}{l}\text { Mean } \\
\text { difference }\end{array}$ & P Value & $\begin{array}{l}\text { Mean } \\
\text { difference }\end{array}$ & P Value & $\begin{array}{l}\text { Mean } \\
\text { difference }\end{array}$ & P Value \\
\hline \multirow{4}{*}{ Body weight } & \multirow{4}{*}{$\begin{array}{l}\text { II } \\
\text { Vs }\end{array}$} & III & 4.167 & 0.879 & -1.667 & 0.997 & $-23.833^{*}$ & 0.001 \\
\hline & & IV & 4.000 & 0.894 & -.333 & 1.000 & $-19.000^{*}$ & 0.007 \\
\hline & & $\mathrm{V}$ & 6.333 & 0.616 & .833 & 1.003 & $-19.167^{*}$ & 0.006 \\
\hline & & VI & 6.333 & 0.616 & .333 & 1.001 & $-22.667^{*}$ & 0.001 \\
\hline
\end{tabular}

*The mean difference is significant at the level of 0.05

Table 4: Change in paw thickness (recorded in $\mathrm{cm}$ ) of different groups of animals on day 0, 12 and 22.

\begin{tabular}{|c|c|c|c|c|c|c|c|c|}
\hline \multirow{3}{*}{ Variables } & \multirow{3}{*}{ Groups } & \multicolumn{2}{|c|}{ Days of study } & & \multicolumn{2}{|l|}{ Day 0-12 } & \multicolumn{2}{|l|}{ Day 12-22 } \\
\hline & & Day 0 & Day 12 & Day 22 & Mean \% & & Mean & \\
\hline & & Mean \pm SD & Mean \pm SD & Mean \pm SD & change & value & $\%$ change & value \\
\hline \multirow{6}{*}{$\begin{array}{l}\text { Paw } \\
\text { thickness }\end{array}$} & I & $0.226 \pm 0.015$ & $0.228 \pm 0.017$ & $0.227 \pm 0.009$ & 3.05 & 0.695 & -3.77 & 0.611 \\
\hline & II & $0.238 \pm 0.029$ & $0.626 \pm 0.034$ & $0.650 \pm 0.021$ & -61.36 & $0.001 *$ & -5.40 & $0.034 *$ \\
\hline & III & $0.213 \pm 0.013$ & $0.616 \pm 0.044$ & $0.348 \pm 0.051$ & -65.41 & $0.001 *$ & 43.52 & $0.001 *$ \\
\hline & IV & $0.221 \pm 0.021$ & $0.618 \pm 0.045$ & $0.540 \pm 0.062$ & -64.05 & $0.001 *$ & 12.44 & $0.026^{*}$ \\
\hline & $\mathrm{V}$ & $0.203 \pm 0.136$ & $0.5267 \pm 0.058$ & $0.521 \pm 0.033$ & -61.40 & $0.001 *$ & 0.95 & 0.845 \\
\hline & VI & $0.201 \pm 0.023$ & $0.5383 \pm 00.041$ & $0.406 \pm 0.032$ & -62.53 & $0.001 *$ & 24.45 & $0.001 *$ \\
\hline
\end{tabular}

All values are represented in mean \pm SD; values on day 0 and 12 represent the value before treatment and values on day 22 are after treatment; $n=6 /$ group; all treatment administered orally; *The mean difference is significant at the level of 0.05 
It was observed that the body weight was reduced in arthritic control group (group-2) on day 22 while it was increased in normal control group (group-1) and treated groups (groups-3 to 6). Treatment with Cyclophosphamide (7mg/kg, group-3) and BSE (180mg, group-6) showed statistically significant improvement in body weight with p-values 0.001 and 0.005 respectively (Tables 3 ).

\section{Effects of BSE on paw thickness as compared to cyclophosphamide}

CFA induced arthritic rats (group-2 to 6) produced a statistically significant increase in paw thickness as compared to normal control group (group-1). Treatment with Cyclophosphamide (group-3) and BSE (groups 4,5and 6) decreased the paw thickness as compared to the arthritic control group. Group-3 $(\mathrm{p}=0.010)$ and group- 6 $(\mathrm{P}=0.024)$ showed a statistically significant decrease in paw thickness (Tables 4 and 5).

Effects of BSE on paw volume as compared to cyclophosphomide
All CFA induced rats showed an increase in paw volume of the right hind as compared to control group (group-1) on day 12 .

Treatment with cyclophosphamide showed a statistically significant decrease in paw volume $(\mathrm{p}=0.010)$ but only high dose of BSE showed significant change $(\mathrm{p}=0.031)$ in paw thickness (Tables 6 and 7).

\section{Effects of BSE on Arthritis Index as compared to cyclophosphomide}

CFA induced arthritic rats produced statistically significant $(\mathrm{P}<0.05)$ increase in the arthritic index in all arthritic group- as compared to normal control group on day 12 .

Treatment with cyclophosphamide showed highly significant reduced in arthritic index score and BSE in dose $180 \mathrm{mg} / \mathrm{kg}$ showed a significant change in the Arthritic index on day 22 with p-value 0.001 and 0.010 respectively (Tables 8 and 9).

Table 5: Change in paw thickness of treated groups as compared with arthritic control group.

\begin{tabular}{|c|c|c|c|c|c|c|c|c|}
\hline \multirow{2}{*}{ Variables } & \multirow{2}{*}{\multicolumn{2}{|c|}{ Groups }} & \multicolumn{2}{|l|}{ Days 0} & \multicolumn{2}{|l|}{ Day 12} & \multicolumn{2}{|l|}{ Day 22} \\
\hline & & & Mean difference & $P$ value & Mean difference & $P$ value & Mean difference & $P$ value \\
\hline \multirow{4}{*}{$\begin{array}{l}\text { Paw } \\
\text { thickness }\end{array}$} & \multirow{4}{*}{$\begin{array}{l}\text { II } \\
\text { Vs }\end{array}$} & III & 0.025 & 0.271 & 0.000 & 1.000 & $0.301^{*}$ & 0.010 \\
\hline & & IV & 0.016 & 0.652 & 0.000 & 1.000 & 0.110 & 0.078 \\
\hline & & $\mathrm{V}$ & 0.035 & 0.057 & 0.090 & 0.061 & 0.128 & 0.057 \\
\hline & & VI & $0.036^{*}$ & 0.042 & $0.078^{*}$ & 0.045 & $0.243^{*}$ & 0.024 \\
\hline
\end{tabular}

$*$ The mean difference is significant at the level of 0.05

Table 6: Change in paw volume (recorded in $\mathrm{ml}$ ) of different groups of animals on day 0,12 and 22.

\begin{tabular}{|c|c|c|c|c|c|c|c|c|}
\hline \multirow{3}{*}{ Variables } & \multirow{3}{*}{ Groups } & \multicolumn{3}{|l|}{ Days of study } & \multicolumn{2}{|l|}{ Day 0-12 } & \multicolumn{2}{|c|}{ Day 12-22 } \\
\hline & & Day 0 & Day 12 & Day 22 & Mean \% & & Mean \% & \\
\hline & & Mean \pm SD & Mean \pm SD & Mean \pm SD & change & value & change & value \\
\hline \multirow{6}{*}{$\begin{array}{l}\text { Paw } \\
\text { volume }\end{array}$} & I & $0.6433 \pm 0.013$ & $0.64 \pm 0.016$ & $0.64 \pm 0.014$ & 0.52 & 1.000 & 0.00 & 0.872 \\
\hline & II & $0.63 \pm 0.015$ & $1 \pm 0.029$ & $1.28 \pm 0.197$ & -37.00 & $0.032 *$ & -28.00 & 0.159 \\
\hline & III & $0.615 \pm 0.042$ & $1.01333 \pm 0.090$ & $0.725 \pm 0.036$ & -39.31 & $0.001^{*}$ & 28.45 & $0.001 *$ \\
\hline & IV & $0.6167 \pm 0.055$ & $1.2267 \pm 0.349$ & $0.895 \pm 0.095$ & -49.73 & $0.010 *$ & 27.04 & 0.073 \\
\hline & V & $0.605 \pm 0.048$ & $0.9867 \pm 0.355$ & $0.86 \pm 0.031$ & -38.68 & $0.001 *$ & 12.84 & $0.002 *$ \\
\hline & VI & $0.5867 \pm 0.021$ & $1.0033 \pm 0.046$ & $0.805 \pm 0.089$ & -41.52 & $0.001 *$ & 19.76 & $0.003 *$ \\
\hline
\end{tabular}

All values are represented in mean \pm SD; values on day 0 and 12 represent the value before treatment and values on day 22 are after treatment; $n=6$ /group; all treatment administered orally; *The mean difference is significant at the level of 0.05

Table 7: Change in paw volume of treated groups as compared with arthritic control group.

\begin{tabular}{|c|c|c|c|c|c|c|c|c|}
\hline \multirow{2}{*}{ Variables } & \multirow{2}{*}{\multicolumn{2}{|c|}{ Groups }} & \multicolumn{2}{|l|}{ Days 0} & \multicolumn{2}{|l|}{ Day 12} & \multicolumn{2}{|l|}{ Day 22} \\
\hline & & & Mean difference & P value & Mean difference & P value & Mean difference & P value \\
\hline \multirow{4}{*}{$\begin{array}{l}\text { Paw } \\
\text { volume }\end{array}$} & \multirow{4}{*}{$\begin{array}{l}\text { II } \\
\text { Vs }\end{array}$} & III & 0.015 & 0.964 & -0.013 & 1.000 & $0.555^{*}$ & 0.010 \\
\hline & & IV & 0.013 & 0.977 & -0.226 & 0.362 & 0.385 & 0.068 \\
\hline & & $\mathrm{V}$ & 0.025 & 0.811 & 0.013 & 1.000 & 0.420 & 0.053 \\
\hline & & VI & 0.043 & 0.350 & -0.003 & 1.000 & $0.475^{*}$ & 0.031 \\
\hline
\end{tabular}

*The mean difference is significant at the level of 0.05 
Table 8: Arthritis index of different groups of animals on day 12 and 22.

\begin{tabular}{|c|c|c|c|c|c|}
\hline \multirow{3}{*}{ Variables } & \multirow{3}{*}{ Groups } & \multicolumn{2}{|c|}{ Days of study } & \multicolumn{2}{|l|}{ Day 12-22 } \\
\hline & & Day 12 & Day 22 & \multirow{2}{*}{ Mean $\%$ change } & \multirow{2}{*}{$P$ value } \\
\hline & & Mean \pm SD & Mean \pm SD & & \\
\hline \multirow{6}{*}{ Arthritic index } & I & $0 \pm 0$ & $0 \pm 0$ & 0.00 & \\
\hline & II & $6.833 \pm 0.389$ & $4.833 \pm 3.157$ & -73.64 & $0.001^{*}$ \\
\hline & III & $7.000 \pm 0.001$ & $1.833 \pm 0.408$ & 50.39 & $0.001 *$ \\
\hline & IV & $6.833 \pm 0.040$ & $5.166 \pm 0.752$ & -38.60 & $0.001^{*}$ \\
\hline & $\mathrm{V}$ & $6.333 \pm 0.816$ & $3.833 \pm 1.329$ & -27.97 & $0.001^{*}$ \\
\hline & VI & $6.666 \pm 0.516$ & $2.333 \pm 0.816$ & -12.61 & $0.046^{*}$ \\
\hline
\end{tabular}

All values are represented in mean \pm SD; values on day 0 and 12 represent the value before treatment and values on day 22 are after treatment; $n=6 /$ group; all treatment administered orally;

*The mean difference is significant at the level of 0.05

Table 9: Change in arthritic index of treated groups as compared with arthritic control group.

\begin{tabular}{|c|c|c|c|c|c|c|}
\hline \multirow{2}{*}{ Variables } & \multirow{2}{*}{\multicolumn{2}{|c|}{ Groups }} & \multicolumn{2}{|l|}{ Day 12} & \multicolumn{2}{|l|}{ Day 22} \\
\hline & & & Mean difference & P Value & Mean difference & P Value \\
\hline \multirow{4}{*}{ Arthritic Index } & \multirow{4}{*}{$\begin{array}{l}\text { II } \\
\text { Vs }\end{array}$} & III & -2.833 & 0.150 & $21.333^{*}$ & 0.001 \\
\hline & & IV & -0.667 & 0.979 & 5.500 & 0.068 \\
\hline & & $\mathrm{V}$ & -1.333 & 0.791 & 6.667 & 0.053 \\
\hline & & VI & -0.167 & 1.000 & $11.000^{*}$ & 0.010 \\
\hline
\end{tabular}

*The mean difference is significant at the level of 0.05

Table 10: TNF- $\alpha$ of different groups of animals on day 12 and 22.

\begin{tabular}{|c|c|c|c|c|c|}
\hline \multirow{3}{*}{ Variables } & \multirow{3}{*}{ Groups } & \multicolumn{2}{|c|}{ Days of study } & \multicolumn{2}{|l|}{ Day 12-22 } \\
\hline & & Day 12 & Day 22 & \multirow{2}{*}{ Mean \% change } & \multirow{2}{*}{$P$ value } \\
\hline & & Mean \pm SD & Mean \pm SD & & \\
\hline \multirow{6}{*}{ TNF $\alpha$} & I & $24.4 \pm 0.51$ & $24.36 \pm 0.517$ & 0.16 & 0.758 \\
\hline & II & $30.57 \pm 1.571$ & $37.32 \pm 1.539$ & -22.08 & $0.001 *$ \\
\hline & III & $30.25 \pm 1.450$ & $27.39 \pm 1.967$ & 9.59 & $0.047 *$ \\
\hline & IV & $30.5 \pm 0.944$ & $35.97 \pm 1.009$ & -17.93 & $0.001 *$ \\
\hline & V & $29.58 \pm 1.169$ & $34.23 \pm 2.865$ & -15.72 & $0.029 *$ \\
\hline & VI & $30 \pm 0.566$ & $31.97 \pm 3.319$ & -6.57 & 0.242 \\
\hline
\end{tabular}

All values are represented in mean \pm SD; values on day 12 represent the value before treatment and values on day 22 are after treatment; $\mathrm{n}=6$ /group; all treatment administered orally

*The mean difference is significant at the level of 0.05

Table 11: Change in TNF- $\alpha$ of treated groups as compared with arthritic control group.

\begin{tabular}{|c|c|c|c|c|c|c|}
\hline \multirow{2}{*}{ Variables } & \multirow{2}{*}{\multicolumn{2}{|c|}{ Groups }} & \multicolumn{2}{|l|}{ Day 12} & \multicolumn{2}{|l|}{ Day 22} \\
\hline & & & Mean difference & P Value & Mean difference & P Value \\
\hline \multirow{4}{*}{ TNF- $\alpha$} & \multirow{4}{*}{$\begin{array}{l}\text { II } \\
\text { Vs }\end{array}$} & III & 0.317 & 0.990 & $9.967^{*}$ & 0.036 \\
\hline & & IV & 0.067 & 1.000 & 1.350 & 0.846 \\
\hline & & V & 0.983 & 0.618 & 3.083 & 0.172 \\
\hline & & VI & 0.567 & 0.922 & $5.350^{*}$ & 0.048 \\
\hline
\end{tabular}

*The mean difference is significant at the level of 0.05

\section{Effects of BSE on serum TNF- a as compared to cyclophosphomide}

In CFA induced arthritic rats, TNF- $\alpha$ was increased as compared to normal control group on day 12 . TNF- $\alpha$ is an inflammatory marker so its increased level promotes inflammation and joint tissue destruction. Treatment with cyclophosphamide showed significant decrease level of serum TNF- $\alpha$ while treatment with BSE also showed a statistical change in high dose $(\mathrm{p}=.036)$ and $(\mathrm{p}=0.048)$ respectively (Tables 10 and 11). 


\section{Histopathological changes}

The histopathological result of an inflamed hind limb of arthritic control (group-2) showed that the synovial membrane was thickened, synovial space was reduced and edematous. The articular cartilage was damaged, blood vessels dilated, and the background was edematous. Dense inflammatory cells were present (Figures 1 and 2).

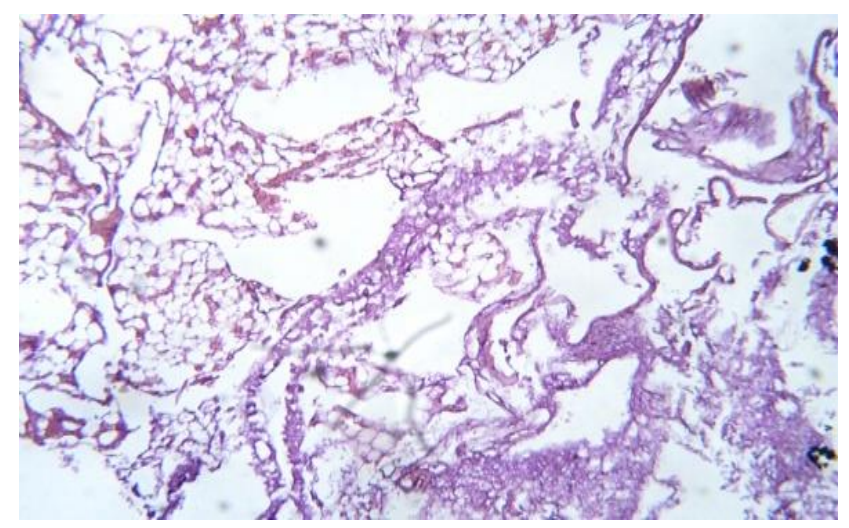

Figure 1: Histopathology of ankle joint cartilage and synovium in arthritis control group showing edema and congestion.

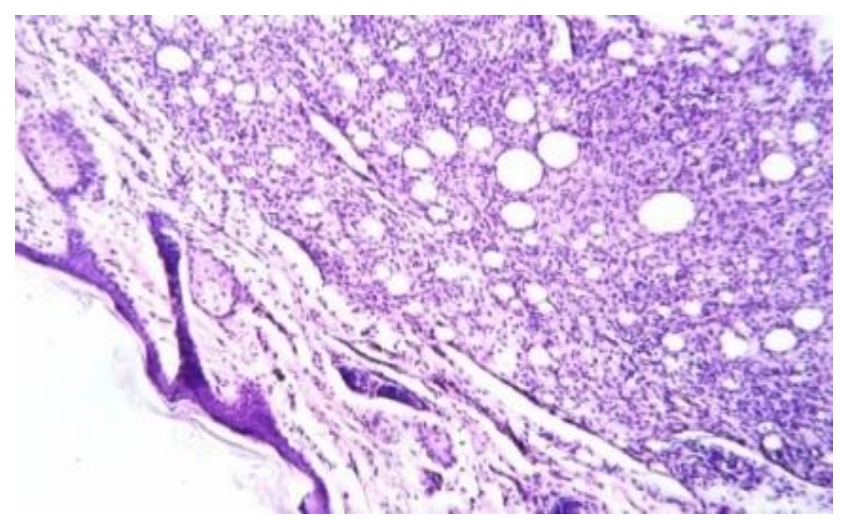

Figure 2: Histopathology of ankle joint bone in arthritis control group showing dense inflammation and pannus.

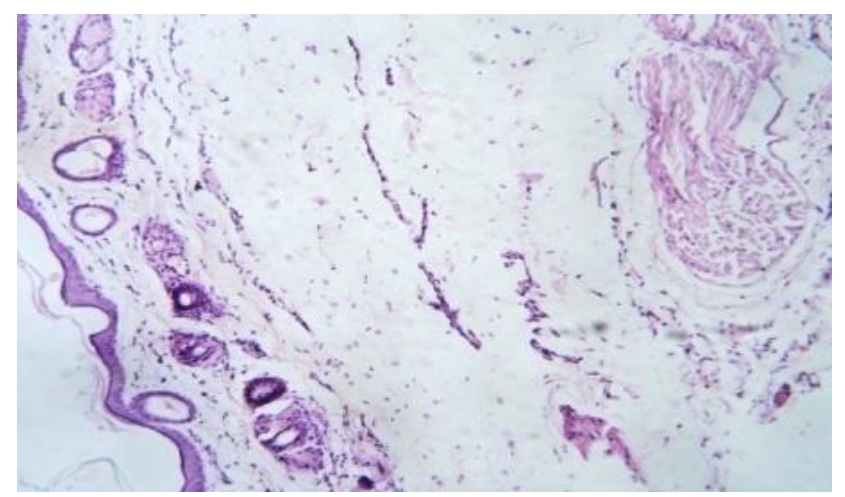

Figure 3: Histopathology of ankle joint cartilage in cyclophosphamide treated group showing improvement.

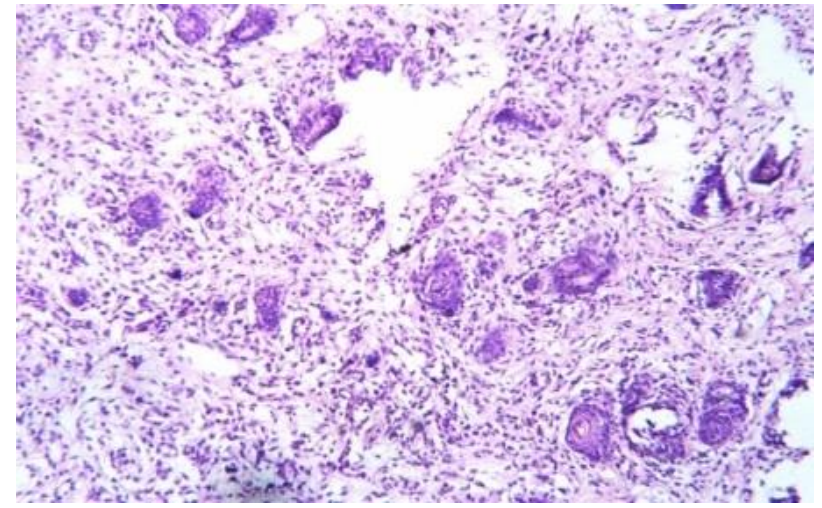

Figure 4: Histopathology of ankle joint bone in cyclophosphamide treated group showing improvement with bone regeneration.

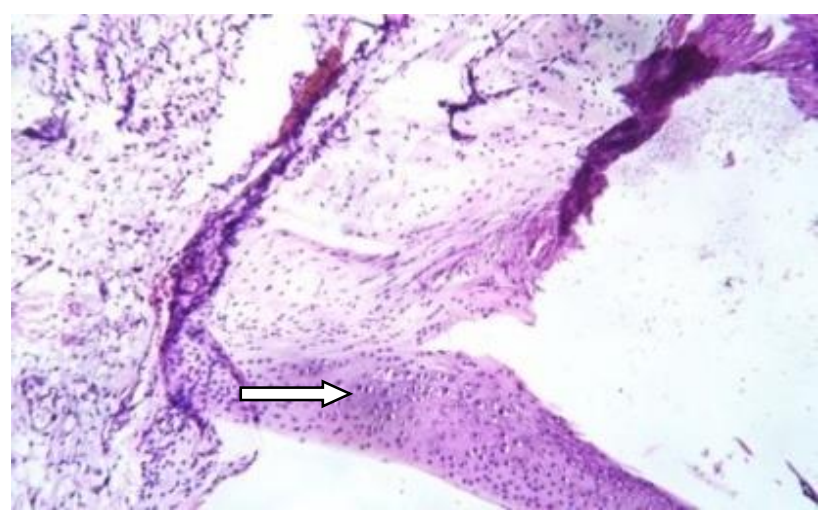

Figure 5: Histopathology of ankle joint cartilage in Boswellia serrata $(180 \mathrm{mg} / \mathrm{kg})$ group showing recovery to normal cartilage (arrow head).

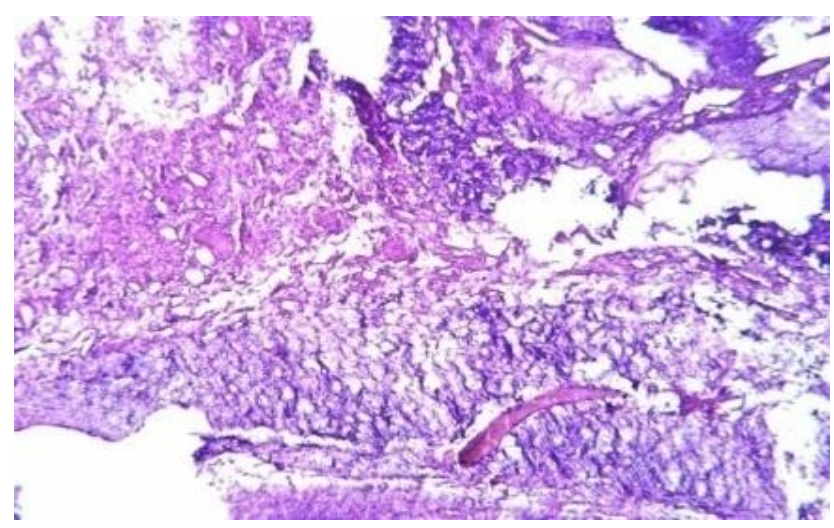

Figure 6: Histopathology of ankle joint bone in Boswellia serrata $(180 \mathrm{mg} / \mathrm{kg})$ group showing reduction in inflammation and cartilage disruption, along with fibro-osseous regeneration.

In Cyclophosphamide $(7 \mathrm{mg} / \mathrm{kg})$ treated (group-III), rats showed a significant low influx of inflammatory cells and revealed a reduction in pannus formation with reduced neutrophil infiltration (Figures 3 and 4). 
BSE treated group-VI $(180 \mathrm{mg} / \mathrm{kg})$ showed reduction in inflammation, cartilage disruption, vascular proliferation, synovial hyperplasia, vasculitis and fibrinoid necrosis along with fibro-osseous regeneration (Figures 5 and 6).

\section{DISCUSSION}

The present experimental study has revealed that the BSE has immune modulatory potential as an antiarthritic drug. This study showed that marked reduction in paw thickness, ankle diameter, paw volume, arthritis index and an improved body weight was found in high dose BSE group but the effect was lesser than standard drug Cyclophosphamide. These changes are in accordance with another study by Umar et al. ${ }^{5}$ Mechanism is not clear but antioxidant status of Boswellia serrata may play a role in its therapeutic effect. ${ }^{12}$

Carefully studied biochemical alterations were further supported by histopathological observations of the joints. High dose of BSE $(180 \mathrm{mg} / \mathrm{kg})$ showed a marked reduction in cartilage disruption, fibro-osseous proliferation, pannus formation, vascular proliferation, synovial hyperplasia, vasculitis and fibrinoid necrosis which are hallmark of RA. BSE treatment was able to decline the histological findings to normal.

This study suggests that the antiarthritic effect of BSE on joints, bone and cartilage in CFA induced arthritic rats was probably mediated by immune modulatory action. Therefore, BSE has significant potential as a phytomedicine and might represent an alternative for classical medicine treatments for chronic inflammatory diseases like rheumatoid arthritis.

Some studies suggest that due to anti-inflammatory and antioxidant properties BSE also found useful in the treatment of Alzheimer's disease, colitis and learning. ${ }^{13-15}$ Authors believe that our results will contribute to the clinical applications in the treatment of rheumatoid arthritis.

\section{CONCLUSION}

Keeping in view the results obtained in the present study, the following conclusions may be drawn regarding the potential effectiveness of BSE against rheumatoid arthritis. An effective and dose-dependent anti-arthritic effect of BSE was clearly evident with more pronounced effect at $180 \mathrm{mg} / \mathrm{kg}$.

However, details of the complete mechanism have not yet been explored. Therefore, further experiments are required to see the effect of further higher doses of BSE in RA and also to elucidate the exact mechanism of action. Also, more specific and longer duration animal and human studies are required to further substantiate the findings of the present study.

\section{ACKNOWLEDGEMENTS}

Authors would like to thank Dr. Sachin Tutu, Dr. Preet Lakhani and Dr. Unnati Saxena for their support during study.

\section{Funding: No funding sources}

Conflict of interest: None declared

Ethical approval: The study was approved by the Institutional Animal Ethics Committee (No.72/IAEC/2016)

\section{REFERENCES}

1. Firestein GS, McInnes IB. Immunopathogenesis of Rheumatoid Arthritis. Immunity. 2017;46(2):183-96.

2. Tak PP, Bresnihan B. The pathogenesis and prevention of joint damage in rheumatoid arthritis: advances from synovial biopsy and tissue analysis. Arthritis Rheum. 2000;43(12):2619-33.

3. Lim H, Lee SH, Lee HT, Lee JU, Son JY, Shin W, et al. Structural Biology of the TNF $\alpha$ Antagonists Used in the Treatment of Rheumatoid Arthritis. Int J Mol Sci. 2018;19(3):768.

4. Siddiqui MZ. Boswellia Serrata, A Potential Antiinflammatory Agent: An Overview. Indian J Pharm Sci. 2011;73(3):255-61.

5. Umar S, Umar K, Sarwar AH, Khan A, Ahmad N, Ahmad S, et al. Boswellia serrata extract attenuates inflammatory mediators and oxidative stress in collagen induced arthritis. Phytomedicine. 2014 May 15;21(6):847-56.

6. Chang Y. Adjuvant polyarthritis. Arthritis Rheum. 1980;23:62-71.

7. Bendele AM. Animal models of rheumatoid arthritis. J Musculoskel Neuron Interact, 2001;1(4):377-85.

8. Ji YY, Wang ZD, Wang SF, Wang BT, Yang ZA, Zhou XR, et al. Ischemic preconditioning ameliorates intestinal injury induced by ischemia-reperfusion in rats. World J Gastroenterol. 2015;21(26):8081-8.

9. Liu HM, Wang KJ. Therapeutic effect of Captopril on rheumatoid arthritis in rats. Asian Pac J Trop Med. 2014;7(12):996-9.

10. Ebrahimpour S, Fazeli M, Mehri S, Taherianfard M, Hosseinzadeh H. Boswellic Acid Improves Cognitive Function in a Rat Model Through Its Antioxidant Activity: - Neuroprotective effect of Boswellic acid. J Pharmacopuncture. 2017;20(1):10-7.

11. Singh D, Nainwani R, Gupta A. In-vivo antiinflammatory and anti-arthritic activity of hydroalcoholic extract of Pongamia Pinnata (L.) Pierre seed. Int J Pharm Pharma Scienc. 2014;6:798-803.

12. Hartmann RM, Martins MI, Tieppo J, Fillmann HS, Marroni NP. Effect of Boswellia serrata on antioxidant status in an experimental model of colitis rats induced by acetic acid. Dig Dis Sci. 2012 Aug 1;57(8):203844.

13. Yassin N, El-Shenawy MA, Mahdy KA, Gouda NAM, El-Fattah A, Marrie $\mathrm{H}$, et al. Effect of Boswellia serrata on Alzheimer's disease induced in rats. J Arab Society Med Resea. 2013;8:1-11. 
14. Gupta I, Parihar A, Malhotra P, Gupta S, Lüdtke R, Safayhi H, et al. Effects of Gum Resin of Boswellia serrata in Patients with Chronic Colitis. Planta Med. 2001;67(5):391-5.

15. Hosseini-Sharifabad M, Kamali-Ardakani R, Hosseini-Sharifabad A. Beneficial effect of Boswellia serrata gum resin on spatial learning and the dendritic tree of dentate gyrus granule cells in aged rats. Avicenna J Phytomed. 2016;6(2):189-97.

Cite this article as: Singh S, Kumar R, Saksena AK, Pal R, Jaiswal R, Kumar R. Immunosuppressant effect of Boswellia serrata extract on CFA induced arthritis in rats. Int J Basic Clin Pharmacol 2018;7:1921-8. 